\title{
Two antimicrobial compounds drimane sesquiterpene polygodial and 11-hydroxydrim-8-en-7-one from the stem bark of Drimys arfakensis Gibbs. (Winteraceae)
}

\author{
Bimo Budi Santoso ${ }^{a,{ }^{*}}$, Hidelisa Padua Hernandez ${ }^{\mathrm{b}}$, Evelyn Bernadeth Rodriguez ${ }^{\mathrm{b}}$, Ida Farida \\ Dalmacio $^{c}$
}

a Department of Chemistry, Faculty of Mathematics and Natural Sciences, University of Papua, Manokwari 98314, Indonesia

b Institute of Chemistry, College of Arts and Sciences, University of the Philippines Los Baños 4031, Philippines

${ }^{c}$ Institute of Biological Sciences, College of Arts and Sciences, University of the Philippines Los Baños 4031, Philippines

* Corresponding author: yanakaresta@gmail.com

\section{Article history}

Submitted 20 December 2017

Revised 12 February 2018

Accepted 7 March 2018

Published Online 30 April 2018

\section{Graphical abstract}

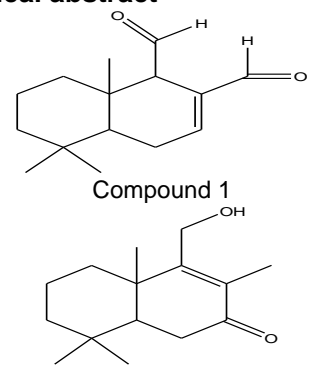

Compound 2

\begin{abstract}
Antimicrobial-guided fractionation and isolation of the bioactive compounds from the stem bark of Drimys arfakensis Gibbs. were carried out. Two antimicrobial compounds were isolated. The structures of the compounds were elucidated by spectroscopic methods such as proton nuclear magnetic resonance $\left({ }^{1} \mathrm{H}\right.$ NMR $)$, carbon-13 nuclear magnetic resonance $\left({ }^{13} \mathrm{C} N \mathrm{NR}\right)$, two-dimensional nuclear magnetic resonance (2-D NMR), and electron ionization-mass spectrometry (EI-MS). Based on the spectroscopic data, the two antimicrobial compounds were polygodial, 1 and 11-Hydroxydrim8-en-7-one, 2. Compound 1 exhibited very strong activity against methicillin-resistant Staphylococcus aureus (MRSA) (B-1823), and yeast-like fungi Candida albicans (B-2219) with both having minimum inhibitory concentration (MIC) values of $7.8 \mu \mathrm{g} \mathrm{mL}^{-1}$. It also showed strong activity against gram negative bacteria Escherichia coli (B-1634) with MIC value of $31.2 \mu \mathrm{g} \mathrm{mL}^{-1}$. While compound 2 only possesses strong activity against $S$. aureus (MRSA), no activity against $C$. albicans and $E$. coli was observed. This is the first report on the antimicrobial activity of compound $\mathbf{2}$ and on the isolation of these two compounds from D. arfakensis Gibbs.
\end{abstract}

Keywords: C. albicans, D. arfakensis, E. coli, polygodial, hydroxydrim-8-en-7-one, S. aureus (MRSA)

(C) 2018 Penerbit UTM Press. All rights reserved

\section{INTRODUCTION}

Drimys is a plant genus that is part of the Winteraceae family. It consists of about fourteen species of evergreen flowering shrubs. Drimys plants feature lance-shaped leaves, fragrant flowers, and black fruits. Plants of this genus are commonly used as border shrubs. Most of the species are adaptable to different soil types, and they are generally free of pests and diseases. These plants are found in primary and secondary tropical forest and usually grow in high altitudes (Heywood, 1993). The species of this genus found in Papua island of Indonesia are D. arfakensis, D. piperita and D. beccariana (Gibbs, 1917).

D. arfakensis, called "akway" in Indonesia, is an upright evergreen flowering shrub with very hot peppery leaves and barks, and attractive white flowers in the terminal head, and grows in full sun and height to around 4-5 meters (Heywood, 1993). The stem barks of $D$. arfakensis are used traditionally as a stimulant by the indigenous people of Manokwari Papua, Indonesia. The tea prepared from the stem barks of $D$. arfakensis are also used against bacterial infections as well as inflammation (Lensee, 2002). Previous work reported that methanol extract from the stem barks of $D$. arfakensis exhibited a wide variety of potent and interesting biological activities (Santoso et al. 2005; Santoso et al., 2007). Previous work reported that the polygodial possessed moderate antibacterial activity against gram-positive bacteria including Bacillus subtilis, S. aureus and gramnegative bacteria including $E$. coli and $S$. choleraesuis with minimum inhibitory concentration (MIC) of 100 and $100 \mu \mathrm{g} \mathrm{mL}^{-1}$ and 100 and
$50 \mu \mathrm{g} \mathrm{mL} \mathrm{L}^{-1}$, respectively (Kubo et al., 2005). It was reported that compound 2 was isolated from fungus Phellinidium sulphurascens and was also shown to be moderately active against a human cancer cell line tested (Zhao et al., 2014). None previous work was found regarding the activity of compound $\mathbf{2}$ against bacteria and fungi.

\section{EXPERIMENTAL}

\section{Materials and equipment}

D. arfakensis Gibbs. was collected from Arfak mountains, District Anggi, Manokwari, West Papua Province, Indonesia in April 2011. The voucher specimen was lodged earlier at The Herbarium Manokwariense, University of Papua, with the identification code BW 279. Melting points were determined by using Fisher-John melting point apparatus. Electron ionization-mass spectrometry (EI-MS) spectra were obtained with GCMS-QP2010S SHIMADZU. Proton nuclear magnetic resonance ( $\left.{ }^{1} \mathrm{H} \mathrm{NMR}\right)$, carbon-13 nuclear magnetic resonance $\left({ }^{13} \mathrm{C} \mathrm{NMR}\right)$, two-dimensional nuclear magnetic resonance (2-D NMR) spectra were determined on an AGILENT spectrophotometer at $500 \mathrm{MHz}\left({ }^{1} \mathrm{H}\right)$ and $125 \mathrm{MHz}\left({ }^{13} \mathrm{C}\right)$. Vacuum Liquid Chromatography (VLC) and radial chromatography utilized silica gel $60 \mathrm{GF}_{254}$ Merck. Radial chromatography was performed on a Harison Research, CHROMATOTRON Model; 8924 instrument. VLC was conducted on $10 \times 8.5 \mathrm{~cm}$ (diameter $\times$ height) and $6 \times 16$ $\mathrm{cm}$ (diameter $\times$ height) glass columns. Analytical TLC used Merck silica gel $\mathrm{GF}_{254}$ aluminum sheet. All reagents used were analytical grade Merck, Sigma and RCI Labscan. 


\section{Extraction}

Finely ground bark $(1500 \mathrm{~g})$ was initially extracted with $5000 \mathrm{ml}$ of hexane for 48 hours. The marc was allowed to dry and the process of extraction was repeated sequentially with dichloromethane (DCM), acetone and finally methanol. The extracts were concentrated in vacuo giving $55 \mathrm{~g}, 42.5 \mathrm{~g}, 48.6 \mathrm{~g}$, and $3 \mathrm{~g}$ of hexane, DCM, acetone, and methanol black-syrupy residues, respectively.

\section{Isolation guided by antimicrobial bioassays}

All four extracts collected by sequential fractionation were tested on $S$. aureus, E. coli and $C$. albicans using cylinder cup and MIC assays. Cylinder cup assay showed that all the extracts were active against $S$. aureus, in which acetone extract was the most active. While hexane extract was the most active against $C$. albicans and none of the extracts was active against $E$. Coli in both assays. Therefore, the acetone and hexane extracts were subjected to fractionation and isolation to get the pure active isolates. Fractionation and isolation of hexane extract were guided by bioautography assay using fungi $C$. albicans and for acetone extract was guided by bioautography assay using S. aureus.

\section{Hexane extract}

Twenty (20) g of hexane extract was subjected to VLC on a $10 \times$ $8.5 \mathrm{~cm}$ (diameter $\times$ height) column using increasing polarity hexane : ethyl acetate solvent systems and finally ethyl acetate. From the VLC of hexane extract was collected twelve fractions. All fractions were then developed on TLC aluminum sheet using solvent system 7 : $3(\mathrm{v}: \mathrm{v})$ hexane : ethyl acetate (EtOAc) and after that subjected to bioautography assay against $C$. albicans. Fraction number nine (HF9) had the highest yield ( $3.29 \mathrm{~g})$ and active against $C$. albicans. A portion (1.5 g) was processed for vacuum liquid chromatography on a $6 \times 16 \mathrm{~cm}$ (diameter $\times$ height) column using hexane : EtOAc solvent system with increasing polarity. A pure isolate $(0.411 \mathrm{~g})$ was collected, called compound 1 .

\section{Acetone extract}

Vacuum liquid chromatography was done to fractionate the acetone extract $(20 \mathrm{~g})$ on a $10 \times 8.5 \mathrm{~cm}$ (diameter $\times$ height $)$ column using hexane : EtOAc solvent systems with increasing polarity and finally ethyl acetate. Twelve fractions labeled AF-1 to AF-12 were collected. TLC plates developed with $7: 3(\mathrm{v}: \mathrm{v})$ hexane : EtOAc were subjected to bioautography assay against $S$. aureus which showed that fraction number 7 (AF-7) was active against $S$. aureus, exhibited good separation and high yield $(2.97 \mathrm{~g})$. Vacuum liquid chromatography of fraction AF-7 (1.5 g) was performed on a $6 \times 16$ $\mathrm{cm}$ (diameter $\times$ height) column using increasing polarity hexane : ethyl acetate solvent systems. Fourteen fractions were collected. TLC was performed on these fractions using solvent system $6: 4$ hexane : EtOAc and then it was tested for activity against $S$. aureus by bioautography. Fraction number 13 (AF-7-13) was active and had a high yield $(236 \mathrm{mg})$. Radial chromatography was performed to fractionate fraction AF-7-13 using solvent systems: chloroform, 9.5 : 0.5 chloroform : EtOAc, $9: 1$ chloroform : EtOAc yielding compound $2(18 \mathrm{mg})$

\section{Test organisms}

Microbial cultures used in the determination of MIC, bioautography and cylinder cup assays were obtained from the Philippine National Collection of Microorganims (PNCM) of BIOTECH, University of the Philippines Los Baños. The microbial cultures used in this project were: Methicillin-resistant Sthapylococcus aureus (MRSA) (B-1823), E. coli (B-1634) and C. albicans (B-2219).

\section{Cylinder cup assay}

A 24-hours old S. aureus (MRSA) and E.coli, and 5-days old culture of $C$. albicans were grown in Mueller Hinton Broth (MHB) and Potato Dextrose Agar (PDA) growth media, respectively. For each bacterial test organism, a loopful of culture was inoculated to a flask with $\mathrm{MHB}$ with $1 \%$ agar. For the fungal test organism, isotonic saline containing $0.05 \%$ Tween was incorporated in the mycelial culture. One $\mathrm{ml}$ of mycelial culture with Tween 80 solution was then inoculated to a flask with PDA. Ten (10) $\mathrm{mL}$ of MHB and PDA were poured on a plate and overlaid with $5 \mathrm{ml}$ seeded top agar. Sterilized assay cylinders were dropped on the plate from a height of $12 \mathrm{~mm}$ using a mechanical guide. The plates were covered to avoid contamination. After filling the cylinders on each plate with $0.1 \mathrm{~mL}$ $10,000 \mu \mathrm{g} \mathrm{mL}^{-1}$ test extract or $0.1 \mathrm{~mL} 1,000 \mu \mathrm{g} \mathrm{mL}^{-1}$ pure isolate and positive control solutions, the bacteria and fungi plates were incubated at $37^{\circ} \mathrm{C}$ for 24 hours and at $35^{\circ} \mathrm{C}$ for 48 hours for bacteria and fungi, respectively. The cylinders were removed and measured to record the diameter of each zone of growth inhibition to the nearest $0.1 \mathrm{~mm}$. Acetone was used as negative control and streptomycin and nystatin was used as positive control for bacteria and fungi, respectively. The diameter of the zone inhibition (ZOI) formed on the triplicate plates was measured using a digital vernier caliper (Gatsing et al., 2010).

\section{MIC against bacterial organism}

With the use of a serological pipette, $100 \mu \mathrm{L}$ of Mueller Hinton Broth (MHB) were pipetted out to the sterile 96-well microtiter plate. Residues of the different extracts and the isolates were re-dissolved in acetone to a concentration of $1 \mathrm{mg} / \mathrm{ml}$. For each of the bacterium used, $100 \mu \mathrm{L}$ aliquot of each plant extract or isolate were two-fold serially diluted with $100 \mu \mathrm{L}$ sterile distilled water in the sterile 96-well microtiter plates loaded with MHB. Then, $100 \mu \mathrm{L}$ of bacterial inocula adjusted to $0.5 \mathrm{McF}$ arland standard were introduced to each 96-well microtiter prepared above. Seven serial dilutions were prepared, ranging from 1,000 to $7.80 \mu \mathrm{g} \mathrm{mL}^{-1}$. A similar two-fold serial dilution of streptomycin (Sigma) of $1 \mathrm{mg} \mathrm{mL}^{-1}$ was used as a positive control against each bacterium, while acetone, as a solvent of the extracts and the isolates, was used as negative control, and distilled water was used as a blank. The plates were covered and incubated overnight at $37^{\circ} \mathrm{C}$. Bacterial growth in the wells was indicated by the presence of turbidity, whereas clear wells indicated inhibition of the bacterial growth by the plant extracts or the pure isolates. The wells with the lowest concentration of the samples which did not exhibit turbidity were reported as the MIC of the samples against the bacterial test organism. The tests were done in triplicate (Ellof, 1998).

\section{MIC against fungal organism}

To determine the MIC against $C$. albicans, the macrobroth dilution assay was used. A 5-days old culture of $C$. albicans was suspended in isotonic saline containing $0.05 \%$ Tween 80 . The mycelial culture was then diluted with more saline until the desired concentration was reached (approximately $10^{6}$ spores $/ \mathrm{ml}$ ). Using a serological pipette, $100 \mu \mathrm{L}$ of Sabourated Dextrose Broth (SDB) (Sigma) was pipetted out to the sterile 96-well microtiter plate. Residues of the different extracts and the isolates were re-dissolved in acetone to a concentration of $1,000 \mu \mathrm{g} \mathrm{mL}^{-1}$. A $100 \mu \mathrm{L}$ aliquot of each plant extract and isolate, tested in triplicate, were two-fold serially diluted with $100 \mu \mathrm{L}$ sterile distilled water in the sterile 96-well microtiter plates loaded with SDB. Then, $100 \mu \mathrm{L}$ of diluted fungal inoculum was introduced to each 96-well microtiter prepared above. Seven serial dilutions were prepared, ranging from 1,000 to $7.80 \mu \mathrm{g}$ $\mathrm{mL}^{-1}$. A similar two-fold serial dilution of nystatin (Sigma) of 1,000 $\mu \mathrm{g} \mathrm{mL} \mathrm{m}^{-1}$ was used as a positive control against fungi, while acetone as a solvent of the extracts and the isolates was used as negative control, and distilled water was used as the blank. The plates were covered and incubated at $35{ }^{\circ} \mathrm{C}$ for 24 hours. Fungal growth in the wells was indicated by the presence of turbidity, whereas clear wells indicated inhibition of the fungal growth by the plant extracts or the pure isolates. The wells with the lowest concentration of the samples which did not exhibit turbidity were reported as the MIC of the samples against the fungal test organism (Fattouch et al., 2007)

\section{Bioautography assay}

Chromatograms of TLC plates prepared were left for four days under an air stream to allow the TLC solvent to evaporate before being overlayed with an actively growing culture of bacteria or fungi. The chromatograms were then incubated for 24 hours at $37^{\circ} \mathrm{C}$ for 
bacteria and 48 hours at $35^{\circ} \mathrm{C}$ for fungi under $100 \%$ relative humidity to allow the microorganisms to grow on the plates. After incubation, the bioautograms were sprayed with an aqueous solution of $2 \mathrm{mg} / \mathrm{ml}$ tetrazolium dye MTT Sigma M2128. The white or yellow zones against dark or pale background indicated inhibition of microbial growth by bioactive compounds in the samples (Hamburger and Cordell, 1987).

Polygodial (1), brownish-yellow oily solid.

MP: $56-59{ }^{\circ} \mathrm{C}$

${ }^{1} \mathrm{H}$ NMR $\left(500 \mathrm{MHz} \mathrm{CDCl}_{3}\right) \delta_{\mathrm{H}} \mathrm{ppm}: 1.832(1 \mathrm{H}, \mathrm{dd}, 2.0,2.3 \mathrm{~Hz}, \mathrm{H}-$ 1)eq, 1.375 (1H, td, 13.5, 3.5 Hz, H-1)ax, 1.557 ( 1H, m, H-2)ax, 1.489 (1H, m, H-2)eq, $1.480(1 \mathrm{H}, \mathrm{m}, \mathrm{H}-3) \mathrm{eq}, 1.238(1 \mathrm{H}, \mathrm{m}, \mathrm{H}-3) \mathrm{ax}$, $1.281(1 \mathrm{H}, \mathrm{m}, \mathrm{H}-5), 2.333$ (1H, m, H-6)eq, $2.518(1 \mathrm{H}, \mathrm{m}, \mathrm{H}-6) \mathrm{ax}$, 7.161 (1H, t, $2.5 \mathrm{~Hz}, \mathrm{H}-7), 2.809(1 \mathrm{H}$, br s, H-9), $9.440(1 \mathrm{H}, \mathrm{d}, 4.5 \mathrm{~Hz}$, H-11), 9.378 (1H, s, H-12), 0.964 (3H, s, H-13), 0.926 (1H, s, H-14), 0.948 and $(1 \mathrm{H}, \mathrm{s}, \mathrm{H}-15)$.

${ }^{13} \mathrm{C}$ NMR $\left(125 \mathrm{MHz}, \mathrm{CDCl}_{3}\right) \delta_{\mathrm{C}} \mathrm{ppm}: 39.5\left(\mathrm{CH}_{2}\right), 18.0\left(\mathrm{CH}_{2}\right), 41.7$ $\left(\mathrm{CH}_{2}\right), 33.0(\mathrm{C}), 48.9(\mathrm{CH}), 25.2\left(\mathrm{CH}_{2}\right), 154.4(\mathrm{CH}), 138.1(\mathrm{C}), 60.2$ $(\mathrm{CH}), 36.8(\mathrm{C}), 201.9(\mathrm{CH}), 193.2(\mathrm{CH}), 21.9\left(\mathrm{CH}_{3}\right), 33.1\left(\mathrm{CH}_{3}\right)$ and $15.1\left(\mathrm{CH}_{3}\right)$.

MS(EI, $70 \mathrm{eV}): m / z(\%): 234\left[\mathrm{M}^{+}\right]$(40), 205(51), 191(30), 151(21), 124(100), 110(45), 109(50)

11-hydroxydrim-8-en-7-one (2), yellowish amorphous solid MP: $83-85^{\circ} \mathrm{C}$

${ }^{1} \mathrm{H}$ NMR (500 MHz, $\left.\mathrm{CHCl}_{3}-\mathrm{d} 1\right) \delta_{\mathrm{H}} \mathrm{ppm}: 2.000(1 \mathrm{H}, \mathrm{dd}, 3.5,12.5 \mathrm{~Hz}$ H-1)eq, 1486 (1H, m, H-1)ax, 1.716(1H, m, H-2)ax, $1.579(1 \mathrm{H}, \mathrm{m}, \mathrm{H}-$ 2)eq, 1.462(1H, m, H-3)eq, 1.232(1H, m, H-3)ax, $1.743(1 \mathrm{H}, \mathrm{dd}, 3.5$, $14.0 \mathrm{~Hz}, \mathrm{H}-5), 2.452(1 \mathrm{H}$, dd, 3.5, $17.5 \mathrm{~Hz}, \mathrm{H}-6) \mathrm{eq}, 2.394(1 \mathrm{H}$, dd, 14.5, 17.5 H-6)ax, $4.367(1 \mathrm{H}, \mathrm{d}, 11.5 \mathrm{~Hz}, \mathrm{H}-11) \mathrm{eq}, 4.316(1 \mathrm{H}, \tilde{\mathrm{n}}, 11.5$ Hz, H-11)ax, 1.864(3H, s, H-12), 0.926(3H, s, H-13), 0.888(3H, s, H14), 1.126(3H, s, H-15).

${ }^{13} \mathrm{C}$ NMR $\left(125 \mathrm{MHz}, \mathrm{CHCl}_{3}-\mathrm{d} 1\right) \delta_{\mathrm{H}} \mathrm{ppm}: 35.5\left(\mathrm{CH}_{2}\right), 18.5\left(\mathrm{CH}_{2}\right)$ $41.2\left(\mathrm{CH}_{2}\right), 33.0(\mathrm{C}), 50.2(\mathrm{CH}), 35.3\left(\mathrm{CH}_{2}\right), 201.4(\mathrm{C}), 132.3(\mathrm{C})$
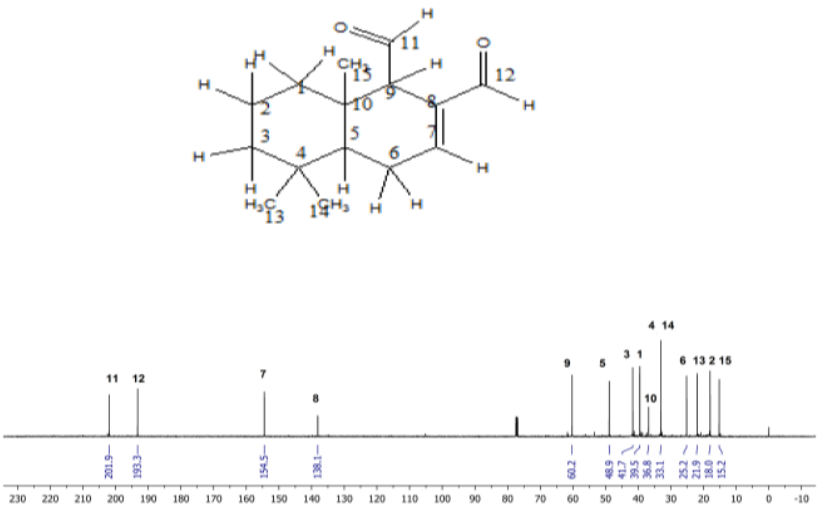

Fig. $1125 \mathrm{MHz}{ }^{13} \mathrm{C}$ NMR Spectrum of Compound-1 in $\mathrm{CHCl}_{3}$-d1.

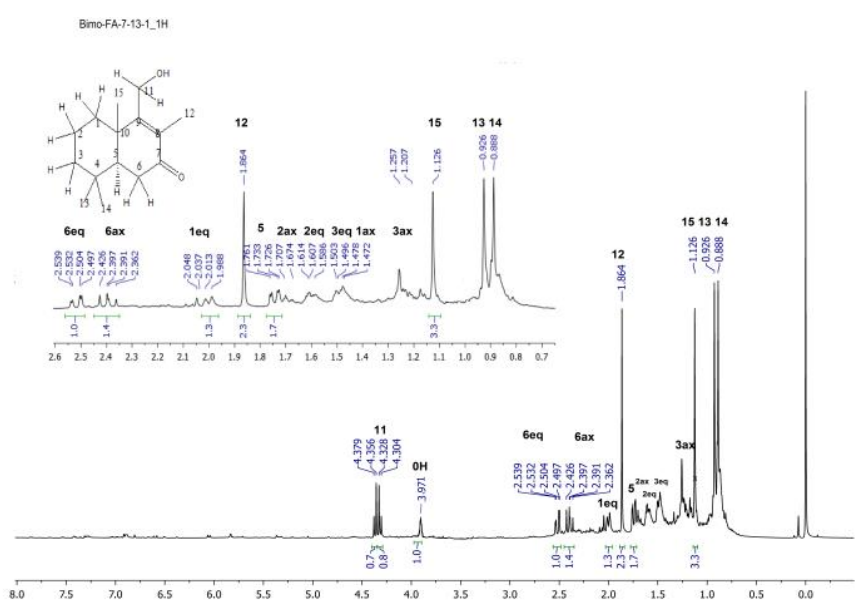

Fig. $3500 \mathrm{MHz}{ }^{1} \mathrm{H}$ NMR spectrum of compound-2 in $\mathrm{CHCl}_{3}$-d1.
$163.1(\mathrm{C}), 40.0(\mathrm{C}), 58.4\left(\mathrm{CH}_{2}\right), 11.3\left(\mathrm{CH}_{3}\right), 21.2\left(\mathrm{CH}_{3}\right), 32.5\left(\mathrm{CH}_{3}\right)$ and $18.3\left(\mathrm{CH}_{3}\right)$

MS (EI, $70 \mathrm{eV}) \mathrm{m} / z(\%): 236\left[\mathrm{M}^{+}\right]$(40), 218(100), 205(43), 190 (35), 127(38), 99 (26), 82 (22), 41 (20).

\section{RESULTS AND DISCUSSION}

Here, we present the results of a chemical study of the stem bark of D. arfakensis gathered from Arfak mountains (West Papua Province, Indonesia). Chromatographic separation of the hexane extract resulted in the isolation of compound $\mathbf{1}$, which was identified as polygodial by NMR spectral data (Figs. 1 and 2) and comparison of its NMR spectral data with that reported in the literature (Aves et al., 2001). This compound has been reported earlier from other Drimys species (Selveira et al., 2012; Melheiros et al., 2001; Melheiros et al., 2005). NMR spectral data of compound 2 (Figs. 3 and 4 resembled those of compound $\mathbf{1}$. These similarities indicated that compound 2 is also a drimane-type sesquiterpene. The ${ }^{13} \mathrm{C}$ NMR spectrum showed a total 15 carbon atoms and the presence of one peak of carbon carbonyl at $\delta$ 201.4. The absence of proton signals at $\delta 9-10$ region on the ${ }^{1} \mathrm{H}$ NMR suggested that carbon carbonyl of $\mathbf{2}$ is a ketone. The double bond was part of compound $\mathbf{2}$ indicated by the appearance two signals at $\delta 163.1$ and 132.3. Instead of the two carbon carbonyls as in compound $\mathbf{1}$, in compound $\mathbf{2}$, they were replaced by an oxygenated carbon and a methyl carbon respectively, as shown by the proton signals at $\delta 4.357(1 \mathrm{H}, \mathrm{d}, \mathrm{J}=11.5 \mathrm{~Hz}, \mathrm{H}-11)$ and $\delta 4.316(1 \mathrm{H}, \mathrm{J}=11.5$ $\mathrm{Hz}, \mathrm{H}-11)$ as well as at $\delta 1.864(3 \mathrm{H}, \mathrm{s}, \mathrm{Me})$. Detailed analysis of its 2D-NMR spectrum and comparison with literature data (Vlad et al., 2000) led to the conclusion that 2 is 11-hydroxydrim-8-en-7-one, which has been previously isolated from fungus Phellinidium sulpurascens (Zhao et al., 2014). To the best of our knowledge, this is the first report on the isolation of compounds $\mathbf{1}$ and $\mathbf{2}$ from $D$. arfakensis.
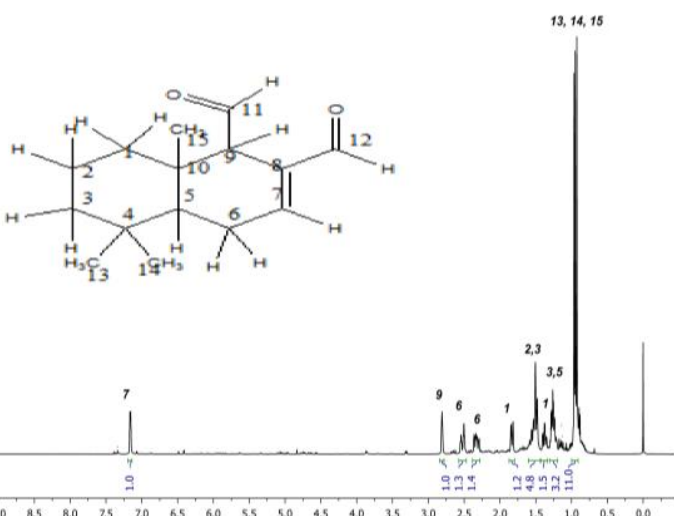

Fig. $2500 \mathrm{MHz}{ }^{1} \mathrm{H}$ NMR spectrum of compound-1 in $\mathrm{CDCl}_{3}$-d1

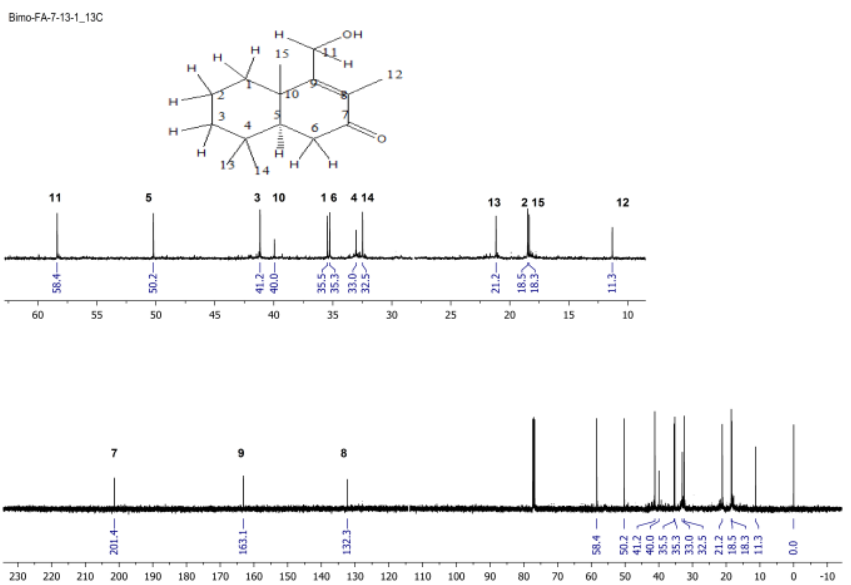

Fig. $4125 \mathrm{MHz}{ }^{13} \mathrm{C}$ NMR spectrum of compound-2 in $\mathrm{CHCl}_{3}$-d1. 
Compound 1, polygodial (Fig. 5) is well known for having a wide range of activities. Previous works reported that polygodial shows activities against several fungi such as Epidermophyton floccosum and Tricophyton rubrum (Melheiros et al., 2005). It shows strong antifungal activity on minimum fungal concentration (MFC) assay, comparable to amphotericin $\mathrm{B}$, against yeast-like fungi $C$. albicans, $C$. utilis, C. krusei, Cryptococcus neoformans, Saccharomyces cerevisiae and also filamentous fungi including Trichophyton mentagrophytes, $T$. ruburum, and Penicillium marneffe (Lee et al., 1999). These reports agree with the findings of this study showing polygodial as possessing strong activity against yeast-like fungi $C$. albicans comparable to positive nystatin. In the cylinder cup assay, polygodial had an inhibition zone of $21.70 \mathrm{~mm}$ while nystatin $23.72 \mathrm{~mm}$. Minimum inhibitory concentration (MIC) assay indicated that polygodial had similar MIC value with nystatin against $C$. albicans at $7.80 \mu \mathrm{g} \mathrm{mL}^{-1}$ (Tables 1 and 2 ).

Table 1 Antimicrobial activity of compounds 1 and 2 on cylinder cup assay.

\begin{tabular}{ccccc}
\hline \multirow{2}{*}{ Compounds } & \multirow{2}{*}{ Dose $(\mu \mathrm{g})$} & \multicolumn{3}{c}{ Diameter of inhibition $(\mathrm{mm})$} \\
\cline { 3 - 5 } & & S. aureus & E.coli & C. albicans \\
\hline $\mathbf{1}$ & 100 & $32.61 \pm 1.32$ & $22.00 \pm 2.30$ & $21.70 \pm 2.10$ \\
$\mathbf{2}$ & 100 & $29.10 \pm 1.42$ & 0.00 & 0.00 \\
Streptomycin & 100 & $18.73 \pm 2.01$ & $22.37 \pm 0.21$ & NT \\
Nystatin & 100 & NT & NT & $23.72 \pm 1.3$
\end{tabular}

$N T=$ not tested. Values are average of three replicates with standard deviation shown.

Table 2 Minimum inhibitory concentration (MIC) of compound 1 and 2.

\begin{tabular}{cccc}
\hline \multirow{2}{*}{ Compounds } & \multicolumn{3}{c}{ Minimum inhibitory concentration $\left(\mu \mathrm{mL}^{-1}\right)$} \\
\cline { 2 - 4 } & S. aureus & E.coli & C. albicans \\
\hline $\mathbf{1}$ & 7.80 & 31.25 & 7.80 \\
$\mathbf{2}$ & 15.60 & $>1000$ & $>1000$ \\
Streptomycin & 7.80 & 7.80 & $\mathrm{NT}$ \\
Nystatin & $\mathrm{NT}$ & $\mathrm{NT}$ & 7.80 \\
\hline $\mathrm{NT}=$ not tested & & &
\end{tabular}

Polygodial was found to possess moderate antibacterial activity against gram-positive bacteria including Bacillus subtilis, S. aureus and gram-negative bacteria including $E$. coli and $S$. choleraesuis with MIC of 50 and $100 \mu \mathrm{g} \mathrm{mL}^{-1}$ and 50 and $50 \mu \mathrm{g} \mathrm{mL}^{-1}$, respectively (Kubo et al., 2005). In this study, polygodial possessed high antibacterial activity against gram-positive bacteria S. aureus (MRSA) and moderate activity against gram-negative bacteria $E$. coli with MIC of 7.80 and $31.25 \mu \mathrm{g} \mathrm{mL}^{-1}$, respectively, as shown in Table 2 . Moreover, in the cylinder cup assay, it showed strong activity against $S$. aureus (MRSA) as well as E.coli with inhibition zones of 32.61 and $22.00 \mathrm{~mm}$, respectively, as compared to streptomycin with inhibition zones of 18.73 and $22.37 \mathrm{~mm}$, respectively (Table 1). In addition, this is probably the first study that tested polygodial on MRSA strain $S$. aureus.<smiles>CC1(C)CCCC2(C)C(C=O)C(C=O)=CCC12</smiles>

Fig. 5 Proposed chemical structure of compound 1.

Compound 2, 11-hydroxydrim-8-en-7-one (Fig. 6) is also a drimane-type sesquiterpene like as polygodial. It is very rarely reported in previous works, specifically with regard to the isolation of this compound and its activity. It was reported that this compound was isolated from fungus Phellinidium sulphurascens and was also shown to be moderately active against a human cancer cell line tested (Zhao et al., 2014). This compound is a valuable synthon for the synthesis of the highly active antifeedant drimane-type sesquiterpene warburganal (Vlad et al., 2000). It exhibited strong activity against $S$. aureus compared to streptomycin in cylinder cup assay which had an inhibition zone of $29.10 \mathrm{~mm}$ compared to streptomycin at $18.73 \mathrm{~mm}$. MIC assay showed that compound 2 had MIC value of $15.60 \mu \mathrm{g} \mathrm{mL}^{-1}$, but it was not active against E. coli and C. albicans (Tables 1 and 2). Both compounds have the same type, namely a drimane-type sesquiterpene but different functional group. Compound $\mathbf{1}$ has two aldehyde groups which both of them near each other, while compound $\mathbf{2}$ consists of hydroxyl and ketone groups These different kinds of structures will affect the different mechanism toward microorganisms and therefore, both compounds have different antimicrobial activity. Based on authors' knowledge, this is the first time that compound $\mathbf{1}$ and compound $\mathbf{2}$ were tested against MRSA strain $S$. aureus. No previous report was found regarding the antimicrobial activity of compound $\mathbf{2}$.<smiles>CC1=C(CO)C2(C)CCCC(C)(C)C2CC1=O</smiles>

Fig. 6 Proposed chemical structure of compound 2.

\section{CONCLUSION}

Two antimicrobial compounds were isolated from the stem bark of $D$. arfakensis and their structures were elucidated by spectroscopic analysis. This was the first time these two compounds were isolated from $D$. arfakensis and probably the first time were tested against $S$. aureus strain MRSA. Detailed analysis on spectral data of compound 1 was found to be drim-7-ene-11,12-dial or poligodial and compound 2 was found to be 11-hydroxydrim-8-en-7-one. Compound 1 exhibited very strong activity against methicillin-resistant Staphylococcus aureus (MRSA) (B-1823), and yeast-like fungi Candida albicans (B-2219) with both having MIC values of $7.8 \mu \mathrm{g}$ $\mathrm{mL}^{-1}$. It also showed strong activity against gram negative bacteria Escherichia coli (B-1634) with MIC value of $31.2 \mu \mathrm{g} \mathrm{mL}^{-1}$. While compound $\mathbf{2}$ only possesses strong activity against $S$. aureus (MRSA), 
no activity against $C$. albicans and $E$. coli was observed. This is the first report on the antimicrobial activity of compound $\mathbf{2}$ and on the isolation of these two compounds from D. arfakensis Gibbs.

\section{ACKNOWLEDGEMENTS}

The author, Bimo B. Santoso, thanks the Directorate General of Higher Education, The Ministry of National Education and Culture, Indonesia and the Southeast Asian Regional Center for Graduate Study and Research in Agriculture (SEARCA) PhD Research Scholarship for the financial support (Ref. No. GCS14-2565).

\section{REFERENCES}

Aves T. M. A., Ribeiro F. L., Kloos H., Zani C. L. 2001. Polygodial, the fungitoxic component from the Brazilian medicinal plant Polygonum punctatum. Mem. Inst. Oswaldo Cruz, 96, 831-833.

Eloff, J. N. 1998. A sensitive and quick microplate method to determine the minimum inhibitory concentration of plant extracts for bacteria. Planto Med., 64, 711-713.

Fattouch, S., Caboni, P., Coroneo, V., Tuberoso, C. I., Angioni, A., Dessi, S. 2007. Antimicrobial activity of Tunisian quince (Cydonia oblonga Miller) pulp and peel polyphenolic extracts. J. Agric. Food Chem., 55, 963-969.

Gatsing, D., Nkeugouapi, C. F. N., Nji-Nkah, B. F., Kuiate, J. R., Tchouanguep, F. M. 2010. Antibacterial activity, bioavailability and acute toxicity evaluation of the leaf extract of Alchornea cordifolia (Euphorbiaceae). Int. J. Pharmacol., 6, 173-182.

Gibbs, L. S. 1917. A contribution to the phytogeography and flora of the Arfak mountains. London: Taylor and Francis.

Hamburger, M. O., Cordell, G. A. 1987. A direct bioautographic TLC assay for compounds possessing antibacterial activity. J. Nat. Prod., 50, 19-22.

Heywood, V. H. 1993. Flowering plants of the world. London: Andromeda
Oxford Ltd.

Kubo, I., Fujita, K., Lee, S. H., Ha, T. J. 2005. Antibacterial activity of polygodial. Phytother. Res., 19, 1013-1017.

Lee, S. H, Lee, J. R., Lunde, C. S., Kubo, I. 1999 In vitro antifungal susceptibilities of Candida albicans and other fungal pathogens to polygodial, a sesquiterpene dialdehyde, Planta Med., 65, 205-208.

Lensee, O. N. 2002. Ethnobotanical study of traditional medicinal plants from Manokwari Regency, West Papua, Indonesia, Master's thesis, James Cook University.

Malheiros, A., Cechinel, V., Schmitt, C., Santos, A., Scheidt, C., Calixto, J., Monache, F., Yunes, R. A. 2001. A sesquiterpene drimane with antinociceptive activity from Drimys winteri bark. Phytochemistry, 57, $103-107$.

Malheiros, A., Cechinel, V., Filho, V., Schmitt, C. B., Yunes, R.A., Escalante, A., Svetaz, L., Zacchino, S., Monache, F. D. 2005 Antifungal activity of drimane sesquiterpenes from Drimys brasiliensis using bioassay-guided fractionation. J. Pharm. Pharm. Sci., 8, 2, 335-339.

Santoso, B. B., Lensee, O. N., Sadsoeitoeboen, M. J., Sjamsul, A. A, Syah, Y. M. 2005. Screening for phytochemicals and antimicrobial activities of medicinal plants from Manokwari Regency. Jurnal Natural Indonesia, 5 , 34- 40 .

Santoso, B. B., Lensee, O. N., Sadsoeitoeboen, M. J., Sjamsul, A. A., Yana, Y M. 2007. Screening for cytotoxicity and antioxidant activities of medicinal plants from Manokwari Regency, Papua, Indonesia. Jurnal Natural Indonesia, 7, 23-28

Silveira, A. C. O., Cludino, V. D., Yunes, R. A., Cechinel, V., Filho, V., Malheiros, A., Cordova, C. M. N., Bella cruz, A. 2012. Antibacterial activity and toxicity of Drimys brasiliensies. Lat. Am. J. Pharm., 31 (7), 93-40.

Vlad, P. F., Popa, D. P, Gorincoi, C. C., Coltsa, M. N., Mironov, G. N. 2000. Synthesis of 11-hydroxydrim-8(9)-en-7-one and 11,12-dihydroxydrim8(9)-en-7-one from drim-8 (9)-en-7-one. Russ. Chem. Bull, 49, 1, 98-101.

Zhao, Z. Z., Chen, H. P., Feng, T., Li, Z. H., Liu, J. K. 2014. Four new sesquiterpenoids from cultures of the fungus Phellinidium sulphurascens. Nat. Prod. Bioprospect., 5, 1, 23-28. 